\title{
Agropedological Approach for Rural Land Use Planning - A Case Study from Lagadwal Village, Dhule District, Maharashtra, India
}

\author{
B.P. Bhaskar*, Sunil Maske, S.C. Ramesh Kumar, S. Srinivas and Rajendra Hegde
}

ICAR-NBSS \& LUP, Regional Centre, Hebbal, Bangalore-560024, Karnataka, India

*Corresponding author

\section{A B S T R A C T}

\section{Keywords}

Crop planning, Dhule, Economic evaluation,

Lagadwal,

Morphopedology,

Rural landscapes

Article Info

Accepted:

24 January 2018

Available Online:

10 February 2018
The decline in crop productivity in rural areas in semi-arid regions of Maharashtra was a serious concern and offered an opportunity to look into the reflective realties of drought and difficulties faced by farmers with rudimentary farming systems. The objectives of present study were to characterize, classify, mapping and evaluation of soils for local grown crops and to integrate crop - livestock systems at landscape level. The cadastral survey was carriedout in Lagadwal village of Dhule district and applied treatment oriented land capability classification to suggest soil-water conservation measures and soil - site suitability for crops. The economic analysis of farming components was carried out by selecting five farmers using soil map. A soil map with 23 soil phases as mapping units were evaluated and estimated that $58.9 \%$ of arable land needs stone wall constructions on summits (8.3\% of area), hill side ditches on shoulder slopes (25.3\% of area), bench and broad base terraces on foot hill ( $9.0 \%$ of area). The onfarm trials with five farmers showed that onion cultivation under broad bed furrow system with poultry + cow component fetched an income of Rs 4.5 lakhs (black soil) over Rs 2.3 lakhs (red soil).

\section{Introduction}

Planning and management of land resources are integral parts of any rural development programme. Land-use planning had negative connotations because it was traditionally associated with top-down procedures. In centrally-planned economies, land users have been ordered how to use their land based on a scientific assessment of its capability or suitability (FAO, 2007). The techniques of land allocation have been adopted from farm planning on the basis of land capability classification to define resource management domains to combine both the socio-economic and biophysical appreciation of land resources (Theobald, 2005). In recent times, the application of GIS tool along with analytical land evaluation models for suitability, area optimization and spatial allocation under different land uses in rural land use planning (Sante Riveira et al., 2008) were extensively used in detailed soil survey and mapping at large scales (at village / watershed level) for holistic farm planning taking into account climate landscape - soil characteristics (Velayutham, 2012). The potentials and constraints of basaltic landscape evaluations for agriculture and rural land use is well recognized (Bhaskar et al., 2011); in mapping 
micronutrient status in southern Villupuram district on 1:50,000 scale using Arc-info GIS 9 (Yoganathan and Meena, 2015) and use of remote sensing in planning land resources of Pulivendula, Andhra Pradesh (Sunitha et al., 2011). The high resolution IRS- PAN-LISSIV satellite sensor data can be registered with cadastral map in generating soil maps for land evaluation exercises (Srivastava and Saxena, 2004; Wadoddkar and Ravi shankar, 2011, Bhaskar et al., 2017; Seal et al., 2017). Under National Agricultural Innovation Project of Rural livelihood security through agroecological planning, the tribal dominated and agriculturally backward Lagadwal village in Dhule district of Maharashtra, was selected for this study. The aim of this article is to focus on relevance of agropedological knowledge in land evaluation exercises by analyzing biophysical constraints and their potentials for development and also integrating important social and economic factors in agricultural planning at landscape level. The basic assumptions of the hypothesis are to have a strategy of natural resource action plan that provides direction in evaluating complex land use issues in drought prone areas on holistic way and working on basaltic landscapes with the idea of potential for agri-development in semiarid tracts of Maharashtra. Hence the objectives of the present study are:

(1) To characterize, classify and mapping of the land resources in lagadwal village; Dhule district

(2) To study the appropriateness and suitability of land evaluation for improving existing cropping systems

(3) To test the integration of cropping systems with a profitable livestock combination in improving economy of farmers through participatory farm management approach.

\section{Materials and Methods}

\section{Study area}

The agricultural landscape in Lagadwal village, Sakri tehsil of Dhule district, Mahrashtra located between $21^{0} 08^{\prime} 01^{\prime \prime} \mathrm{N}$ latitude and $74^{\circ} 06^{\prime} 51^{\prime \prime} \mathrm{E}$ longitude and is dominated by dykes and residual hills of the Sahyadri Spurs with shallow to stony soils (Fig. 1). The major part of the area is covered by basaltic flows commonly known as Deccan Traps intruded by dykes of Upper CretaceousLower Eocene age. The Deccan Trap includes several flows of basalt, which are supposed to have extruded from fissure volcanoes that includes the "pahoehoe" and the "aa" types of flows, the former being very common (Deolankar, 1980). This area has hot semiarid ecosystem with a length of growing period of 120 - 150 days (Agroecoregion of K4Dd4) Velayutham et al., 1999). The study area is totally under rainfed and heavily depends on regular Monsoon. Apart from wheat, bajra, sorghum, onion is the most favoured one in the region. As much as $80 \%$ of the population is tribal. The prominent tribes inhabiting these tropical dry deciduous forests are Bhil, Pawara, Kokani, Mavchi, Gavit and Dhank (Patil and Bhaskar, 2007).

The cultivated crops in the village are sorghum (Sorghum bicolor), bajra (Pennisetum graminae), maize (Zea mays), wheat (Triticum aestivum), sugar cane (Saccharum officinarum), chillies (Capsicum annuum) and brinjal (Solanum melogena). The natural vegetation consists of trees viz., Gunj - Abrus precatorius, Hivvar - Aegle marmelos, Piwala - dhotra - Argemona mexicana, Neem - Azadirachta indica, Katesawar - Bombax ceiba, Rui - Calotropis gigantea, Dhak - Butea monosperma, Bahawa - Cassia fistula, Sisam - Dalbergia sissoo, Lokhadi - Ehretial aevis, Ghuteumbar - Ficus heterophylla, Umbar - Ficus racemosa, Sabar 
- Euphorbia neriifolia (Patil and Patil, 2007). The total population in the village is 1169 , out of which 745 are illiterate $(63.73 \%$ of population) and $424(36.2 \%)$ are literates. Regarding gender wise literacy, male has $21.64 \%$ and Female with $14.62 \%$. The total cultivators are 384 of which $19.58 \%$ are male and $13.25 \%$ are female. The village has 213 agricultural labourers of which $5.56 \%$ is only male and $12.7 \%$ are female (Fig. 2).

The two step methodological approach was adopted in this study involving preliminary landscape analysis at farm scale in terms of topography, geology and land use at Lagadwal village of Dhule district, Maharashtra. The first step was based on detailed soil survey on 1:10000 scale cadastral map covering 664 hectares of land in Lagadwal village of sakri tehsil, Dhule district, Maharashtra as per the guidelines of Soil Survey Staff (2014). The intensive field traverses were made to check field boundaries and to acquaint with landscape patterns. Nine representative soil transects with fifty seven soil profiles were studied in different locations and recorded latitude, longitude and elevation of each soil site with the help of hand held Global Positioning System (GPS) and described morphological descriptions of each pedon (Schoeneberger et al., 2012). These soils were classified upto subgroup level in the soil orders of Entisols, Inceptisols, Alfisols and Vertisols. Air-dried samples were gently crushed and passed through a $2 \mathrm{~mm}$ sieve and analysis were done using fine earth. Soil texture was analysed using the pipette method with distilled water and dispersion through 3hours shaking with Na-hexametaphosphate (Gee and Bauder, 1986). Reaction was measured potentiometrically in 1:2.5 soil water ratio with a glass electrode. Electrical conductivity was measured in a 1:2.5 suspension (soil: $\mathrm{H}_{2} \mathrm{O}$ ) using conductivity meter. The analysis of organic carbon was estimated using the Walkley - Black Wet Oxidation method (Nelson and Sommer,
1982); Cation exchange capacity (CEC) was determined by ammonium saturation method at $\mathrm{pH}$ 7. The exchangeable bases were measured using Atomic absorption spectrophotometer (Perkin elmer model). The available fraction of $\mathrm{Fe}, \mathrm{Mn}, \mathrm{Cu}$ And $\mathrm{Zn}$ were extracted with DTPA - TEA buffer $(0.005$ MDTPA+ $0.01 \mathrm{M} \mathrm{CaCl}_{2}+0.1 \mathrm{M}$ TEA) and concentration of $\mathrm{Fe}, \mathrm{Mn}, \mathrm{Cu} \& \mathrm{Zn}$ in the DTPA extracts was determined in an Atomic Absorption Spectrophotometer (Lindsay and Norvell, 1978).

The soil map was generated with mapping units defined as phases of each series in GIS environment with ARCINFO. Ver. 8. The land capability classification (Klingebiel and Montgomery, 1961), treatment oriented land capability classification as per scheme to suggest soil-water conservation measures 23 (Sheng, 1972) and soil-site suitability for crops24 as per Sys et al., (1991).

\section{Participatory farm management approach}

Evaluation of farming components was carried out by selecting five farmers having land parcel in soil mapping unit 4, 10, 16 and 18 (Table 1) with on farm demonstration trials of crop - livestock components and economic analysis of beneficiaries under study. The methodology for participatory farm management method is given in a diagrammatic representation in Figure 2 and 3. During participatory farm management method, the basic guidelines described by Chambers (2003) were followed but the farm components chosen as per the local preference of farmers for collation and analysis within the site specific context. The three farming systems identified from each category viz., marginal (<1ha) - field crops - livestock, small (1-2ha) - field crops - vegetable - live stock and medium (2-5ha) - field crops horticrops- livestock. Briefly the steps involved in this study were given as under: 
(1) Baseline survey of village regarding agricultural inventory and land resource characterization

(2) Discussion among expert groups and then with local farmers to identify technical interventions useful to solve agricultural issues.

(3) Consensus on local priorities and prepared crop - livestock programmes to validate crop plan

(4) Implementation of participatory land use plan for each category of land holders in the village

\section{Results and Discussion}

\section{Characterization and classification of soils}

The village covers 664 hectares of land (ha) having high basaltic rises with thin forest cover (> 620m above mean sea level) with extremely shallow Lithic Ustorthents (Budkhed series -P1) and are used for the cultivation of bajra and black gram in patches. The Budkhed series (P1) is extremely shallow with clay loam texture (clay content of 29 to 35 per cent) and fine loamy particle size class. The surface horizon is neutral with 1.05 per cent of organic carbon and DTPA extractable zinc of $0.38 \mathrm{mg} / \mathrm{kg}$. The exchangeable complex is dominated by $\mathrm{Ca}(19.2 \mathrm{cmol} / \mathrm{kg})$, $\mathrm{Mg}(10.1 \mathrm{cmol} / \mathrm{kg})$ and $\mathrm{K}(1.2 \mathrm{cmol} / \mathrm{kg})$ in surface horizon (Table 1).

The mid hills (600 to $620 \mathrm{~m}$ ) have extremely shallow Lithic Typic Ustorthents (Lagadwal P3) under bajra, groundnut, redgram cultivation on crests. This series (P3) is slightly acid with fine loamy particle size class (clay of 19 to 26 per cent), exchangeable $\mathrm{Ca}$ of 21 to $32.3 \mathrm{cmol} / \mathrm{kg}$ and DTPA extractable $\mathrm{Zn}$ of $0.72 \mathrm{mg} / \mathrm{kg}$. Brahmasila series (P4) is very deep and fine loamy textured (clay content in control section $(25-100 \mathrm{~cm})$ is 29.47 per cent,
Soil Survey Staff, 2014). This soil has neutral surface layer with moderately alkaline slickensided zones having exCa to ex. $\mathrm{Mg}$ ratio more than 1 with its contents varying from 19 to $32 \mathrm{cmol} / \mathrm{kg}$. These soils have DTPA extractable $\mathrm{Zn}$ below critical limit $(0.8 \mathrm{mg} / \mathrm{kg})$. The Gakot series (P5) is very deep with neutral to slightly alkaline and moderately alkaline slickensided zones. This soils has more than 1 per cent of organic carbon throughout depth except in Bss2 layer $(72-102 \mathrm{~cm})$ and an increase of exchangeable magnesium from 36.9 to $48.4 \mathrm{cmol} / \mathrm{kg}$ with DTPA extractable zinc $(0.44 \mathrm{mg} / \mathrm{kg})$ in that particular layer. Lagadwal tola series (P6) is very deep, fine loamy textured (clay in control section is 32.01 per cent) and neutral to slightly acid with an exchangeable $\mathrm{Ca}$ of 25 to $32 \mathrm{cmol} / \mathrm{kg}, \mathrm{Mg}$ of 12.8 to $20.1 \mathrm{cmol} / \mathrm{kg}$. The DTPA extractable $\mathrm{Zn}$ in this soil is 0.38 to $0.52 \mathrm{mg} / \mathrm{kg}$ which is below critical limit.

The low hills (580 to $600 \mathrm{~m}$ ) have moderately deep Typic Haplustepts (Lagadwal thana series) and Typic Haplustalfs (Navgaon series) Lagadwal thana series (P7) has loamy texture with sand content of 35 to 46 per cent, silt of 39 to 50 per cent and clay of 15 to 16 per cent. The particle size class is defined as fine loamy at family level as clay content is 21.74 per cent. This soil has slightly acid to neutral with 0.96 to 0.61 per cent of organic carbon. The calcium is dominant on exchange complex with its values ranging from 21.1 to 30.3 $\mathrm{cmol} / \mathrm{kg}$. Next to calcium, magnesium is dominant with its contents from 12.9 to 17.49 $\mathrm{cmol} / \mathrm{kg}$, Na of 0.39 to $0.55 \mathrm{cmol} / \mathrm{kg}$ and $\mathrm{K}$ of 0.25 to $0.56 \mathrm{cmol} / \mathrm{kg}$. Among DTPA extractable elements, Zinc in subsoils is in deficient range $(0.34$ to $0.36 \mathrm{mg} / \mathrm{kg})$. The Navgaon series (P2) is well drained, moderately shallow, slightly acid to neutral and fine loamy (clay of 9.92 to 24.9 per cent). This soils has 18.8 to $27.6 \mathrm{cmol} / \mathrm{kg}$ exchangeable $\mathrm{Ca}, 10.9$ to $14.3 \mathrm{cmol} / \mathrm{kg} \mathrm{Mg}$ and irregular distribution of DTPA extractable $\mathrm{Zn}$ of 0.48 to $0.98 \mathrm{mg} / \mathrm{kg}$. Like this, in many of 
soil resource mapping exercises, the wide spread of $\mathrm{Zn}$ deficiency in this kind of red black soil associations were reported in southern Villupuram district, Tamil nadu (Yoganathan and Meena, 2015).

The red soil series namely Budkhed, Lagadwal, Lagadwalthana and Navgaon are in association with black soil series such as Gaikot, Brahmasila and Lagadwaltola in mid and low hills of Lagadwal village. Such kind of red-black" soil catena with "red soils" on the higher positions of the landscape, and black vertisols in the lower positions were reported (Bhaskar et al., 2011). This kind of soil-landscapes are put under dryland agriculture during kharif season starting from June to September and for rabi crops (wheat, maize and groundnut) from November to February wherever irrigation facilities are available.

\section{Mapping of soils}

The distribution of soil series in the study area as shown in the soil map consists of generic characteristics of seven soil series at 23 phases depicted as mapping units (Fig. 4, Table 2). The mapping units is defined as per the guidelines of AISLUS (1970) considering texture, series name, erosion and slope class as symbolized: - iB2F (where I = sandy clay, B = budkhed series, $2=$ moderate erosion and $\mathrm{F}=$ $>15$ per cent slope). It is observed that only three mapping units occupied more than 10 per cent of total area in the village viz., iB3F (96.7ha, 14.6 per cent), mN2B (78.1ha, 11.8 per cent) and mN2C (94ha, 14.2 per cent). Regarding depth classes (Sehgal, et al., 1987), the soil series is arranged as follows: extremely shallow -Budkhed and Lagadwal, shallow - Lagadwalthana, moderately shallowLagadwaltola and Navgaon, deep - Gaikot and very deep - Brahmasila. Considering the slope $>15$ per cent not suitable for mechanization and stony features in high, mid and low hills, the 10 mapping units are classified under non arable covering 272.08 ha (40.98 per cent).

\section{Land capability classification}

To use every piece of land according to or within its capability is probably the first step toward any soil survey programme, at that time, used a land capability classification derived from the USDA system. The classification has caused some dilemma to the small farmers making living on steep slopes (>20\%). Using that classification system, the area has thirteen mapping units covering 58.99 per cent of total area (391.72ha) is under arable class. Out of 58.99 percent of arable land, 14.67 per cent of land is classified as Class II land whereas 19.78 per cent of land is classified as Class III and 24.54 per cent as Class IV land (Table 3). The Class IV lands (24.54 per cent) have severe limitations of moderate to steep slopes with shallow infertile soils. These lands are capable of supporting grazing and forest is often the best land use. It was apparent then 'Treatment-oriented' land capability classification was proposed for steep lands to put under intensive agriculture with prescribed conservation practices (Sheng, 1972) and summary of results presented in table 3 . In this system of classification, slope and soil depth as major factors plus considering other soil limiting factors (stony, wet, severe erosion) are considered to classify each piece of land with conservation treatment (s) to follow in the study area. The summits under high hills cover 8.3 per cent of total area with extremely shallow Budkhed series which needs stone wall construction while side slopes (14.6 per cent of total area) and narrow shoulder slopes (6.7 per cent) with Lagadwal series needs hill side ditches. Likewise for mid hills, the crest slopes having moderately shallow Navgaon (36.9 per cent of total area) and Lagadwal thana (1.7 per cent of total area), the suggested conservation methods are hill side ditches and stone wall construction. 
Table.1 Physical and chemical characteristics of soils under study

\begin{tabular}{|c|c|c|c|c|c|c|c|c|c|c|c|c|c|c|c|c|}
\hline \multirow[t]{2}{*}{ Horizon } & \multirow[t]{2}{*}{$\begin{array}{l}\text { Depth } \\
\text { (cm) }\end{array}$} & \multicolumn{3}{|c|}{$\begin{array}{l}\text { Paricle size } \\
\text { distribution }(\%)\end{array}$} & \multirow[t]{2}{*}{ pH } & \multirow{2}{*}{$\begin{array}{l}\text { EC } \\
\text { (dSm- } \\
\text { 1) }\end{array}$} & \multirow[t]{2}{*}{$\begin{array}{l}\mathrm{OC} \\
(\%)\end{array}$} & \multicolumn{4}{|c|}{$\begin{array}{l}\text { Exchangeable } \\
\text { bases(cmol/kg) }\end{array}$} & \multirow[t]{2}{*}{$\begin{array}{l}\text { Available } \\
\text { K(mg/kg) }\end{array}$} & \multicolumn{4}{|c|}{ DTPA Extractable(mg/kg) } \\
\hline & & Sand & silt & Clay & & & & $\mathrm{Ca}$ & $\mathrm{Mg}$ & K & $\mathrm{Na}$ & & $\mathrm{Fe}$ & $\mathrm{Mn}$ & $\mathrm{Cu}$ & $\mathrm{Zn}$ \\
\hline \multicolumn{17}{|c|}{ P1.Budkhed (Lithic Ustorthents) } \\
\hline Ap & $0-9$ & 25.1 & 39.6 & 35.2 & 6.5 & 0.054 & 1.05 & 19.2 & 10.1 & 1.20 & 0.39 & 44.8 & 28.08 & 52.8 & 6.92 & 0.38 \\
\hline $\mathbf{r}$ & $9-47$ & 23.9 & 46.3 & 29.7 & 6.2 & 0.092 & 1.03 & 23.2 & 18.0 & 0.51 & 0.43 & 114.2 & 44.66 & 61.5 & 18.0 & 0.92 \\
\hline \multicolumn{17}{|c|}{ P2. Navgaon series } \\
\hline $\mathbf{A p}$ & $0-16$ & 29.88 & 60.2 & 9.9 & 6.2 & 0.75 & 1.13 & 18.8 & 10.9 & 0.53 & 0.39 & 118.7 & 64.4 & 100.5 & 18.5 & 0.98 \\
\hline Bt1 & $16-41$ & 17.23 & 57.87 & 24.9 & 6.6 & 0.041 & 1.07 & 22.2 & 10.9 & 0.56 & 0.43 & 125.4 & 51.92 & 69.8 & 13.0 & 0.48 \\
\hline Bt2 & $41-63$ & 22.85 & 56.75 & 20.4 & 6.8 & 0.039 & 0.79 & 27.6 & 14.3 & 0.51 & 0.43 & 114.2 & 25.94 & 110.0 & 12.5 & 0.88 \\
\hline \multicolumn{17}{|c|}{ P3.Lagadwal series } \\
\hline Ap & $0-8$ & 51.47 & 38.73 & 9.80 & 6.7 & 0.12 & 0.99 & 21.7 & 11.9 & 0.48 & 0.52 & 107.5 & 54.8 & 69.2 & 14.0 & 0.72 \\
\hline \multicolumn{17}{|c|}{ P4.Brahmasila } \\
\hline Ap & $0-11$ & 16.87 & 49.58 & 33.55 & 7.20 & 0.045 & 0.568 & 26.5 & 18.9 & 0.75 & 0.71 & 33.6 & 52.4 & 29.4 & 5.9 & 0.48 \\
\hline Bw1 & $11-31$ & 15.35 & 45.01 & 39.64 & 7.22 & 0.042 & 0.549 & 32.1 & 21.2 & 0.78 & 0.85 & 34.94 & 48.3 & 31.2 & 8.8 & 0.38 \\
\hline Bss1 & $31-66$ & 13.50 & 61.3 & 25.20 & 8.17 & 0.128 & 0.176 & 30.1 & 20.4 & 0.81 & 0.73 & 36.28 & 46.4 & 30.4 & 7.3 & 0.36 \\
\hline Bss2 & $66-94$ & 24.11 & 40.43 & 35.46 & 8.24 & 0.129 & 0.098 & 29.6 & 19.6 & 0.78 & 0.69 & 34.94 & 45.5 & 29.8 & 10.2 & 0.28 \\
\hline Bss3 & $\begin{array}{l}94- \\
120\end{array}$ & 34.07 & 32.05 & 33.88 & 8.30 & 0.117 & 0.078 & 24.5 & 18.7 & 0.62 & 0.53 & 27.77 & 50.6 & 32.6 & 11.2 & 0.43 \\
\hline Bss4 & $\begin{array}{l}120- \\
150\end{array}$ & 22.22 & 48.02 & 29.76 & 6.34 & 0.089 & 2.262 & 27.3 & 18.0 & 0.52 & 0.72 & 23.29 & 48.8 & 30.7 & 8.8 & 0.40 \\
\hline \multicolumn{17}{|c|}{ P5.Gaikot series } \\
\hline$\overline{\mathrm{Ap}}$ & $0-14$ & 12.95 & 42.6 & 44.5 & 3.9 & 0.036 & 1.07 & 44.3 & 36.9 & 0.89 & 0.69 & 39.87 & 24.36 & 66.2 & 16.2 & 1.2 \\
\hline Bw1 & $14-37$ & 22.9 & 31.1 & 46.0 & 7.2 & 0.049 & 1.08 & 35.0 & 42.9 & 1.09 & 0.75 & 48.83 & 77.42 & 49.6 & 14.2 & 1.04 \\
\hline Bss1 & $37-72$ & 10.3 & 43.8 & 45.9 & 7.3 & 0.057 & 1.18 & 35.3 & 39.6 & 1.02 & 0.59 & 26.43 & 66.7 & 47.4 & 15.2 & 1.0 \\
\hline Bss2 & $\begin{array}{l}72- \\
102\end{array}$ & 33.6 & 24.83 & 41.6 & 7.6 & 0.087 & 1.1 & 37.2 & 48.4 & 0.86 & 0.72 & 38.52 & 60.28 & 27.4 & 13.6 & 0.78 \\
\hline Bss3 & $\begin{array}{l}102- \\
152\end{array}$ & 14.0 & 44.7 & 41.5 & 7.8 & 0.052 & 0.29 & 37.8 & 41.9 & 0.92 & 0.62 & 41.21 & 37.6 & 43.8 & 4.8 & 0.44 \\
\hline \multicolumn{17}{|c|}{ P6. Lagadwal tola } \\
\hline$\overline{A p}$ & $0-12$ & 34.53 & 35.44 & 30.03 & 7.05 & 0.035 & 0.98 & 25.6 & 15.4 & 0.59 & 0.55 & 26.43 & 48.6 & 30.6 & 11.0 & 0.38 \\
\hline$\overline{B w 1}$ & $12-41$ & 21.75 & 58.08 & 25.17 & 7.38 & 0.046 & 0.99 & 28.9 & 19.4 & 0.99 & 0.68 & 41.66 & 46.7 & 33.7 & 12.3 & 0.42 \\
\hline Bss1 & $41-63$ & 39.20 & 25.11 & 35.69 & 7.58 & 0.039 & 0.53 & 30.1 & 20.1 & 0.84 & 0.69 & 37.63 & 50.8 & 30.1 & 14.5 & 0.52 \\
\hline $\mathbf{B c}$ & $\begin{array}{l}63- \\
102\end{array}$ & 28.19 & 39.03 & 32.78 & 7.16 & 0.084 & 0.71 & 32.1 & 12.8 & 0.82 & 0.72 & 36.73 & 50.2 & 28.2 & 10.6 & 0.32 \\
\hline \multicolumn{17}{|c|}{ P7. Lagadwal thana series } \\
\hline $\mathbf{A p}$ & $0-16$ & 45.89 & 39.28 & 14.97 & 6.45 & 0.084 & 0.97 & 21.1 & 12.91 & 0.33 & 0.39 & 73.92 & 47.86 & 62.6 & 8.00 & 0.84 \\
\hline Bw1 & $16-32$ & 34.70 & 50.26 & 19.49 & 6.79 & 0.058 & 0.71 & 27.2 & 14.08 & 0.38 & 0.48 & 85.12 & 41.14 & 50.8 & 8.32 & 0.36 \\
\hline Bw2 & $32-65$ & 44.21 & 40.82 & 26.12 & 7.09 & 0.063 & 0.614 & 30.3 & 14.33 & 0.25 & 0.52 & 56.0 & 22.86 & 16.8 & 3.46 & 0.34 \\
\hline
\end{tabular}


Table.2 Area and description of soil mapping units

\begin{tabular}{|c|c|c|c|c|}
\hline \multirow{2}{*}{$\begin{array}{l}\text { S. } \\
\text { No. }\end{array}$} & \multirow{2}{*}{$\begin{array}{l}\text { Mapping } \\
\text { Unit }\end{array}$} & \multirow[t]{2}{*}{ Mapping Unit Description } & \multicolumn{2}{|l|}{ Area } \\
\hline & & & (ha) & $\%$ \\
\hline 1 & iB3F & $\begin{array}{l}\text { Budkhed: sandy clay, severe erosion with } 15-25 \% \text { slope, moderately } \\
\text { gravelly }\end{array}$ & 96.7 & 14.6 \\
\hline 2 & $\mathrm{mB} 2 \mathrm{E}$ & $\begin{array}{l}\text { Budkhed: gravelly clay, moderately erosion with } 3-5 \% \text { slope, very } \\
\text { gravelly }\end{array}$ & 54.8 & 8.3 \\
\hline 3 & iB3E & $\begin{array}{l}\text { Budkhed: sandy clay, severe erosion with } 10-15 \% \text { slope, slightly } \\
\text { gravelly }\end{array}$ & 4.7 & 0.7 \\
\hline 4 & $\mathrm{mN} 2 \mathrm{~B}$ & Navagaon: clayey, moderate erosion with $1-3 \%$ slope & 78.1 & 11.8 \\
\hline 5 & $\mathrm{mN} 3 \mathrm{E}$ & $\begin{array}{l}\text { Navagaon: clayey, severe erosion with } 10-15 \% \text { slope, moderately } \\
\text { gravelly }\end{array}$ & 3.8 & 0.6 \\
\hline$\overline{6}$ & $\mathrm{mN} 2 \mathrm{C}$ & Navagaon: clayey, moderately erosion with $3-5 \%$ slope, slightly gravelly & 10.9 & 1.7 \\
\hline 7 & $\mathrm{iN} 3 \mathrm{~F}$ & $\begin{array}{l}\text { Navagaon: sandy clay, severe erosion with } 15-25 \% \text { slope, very gravelly } \\
\text { with wide gullies }\end{array}$ & 3.0 & 0.5 \\
\hline 8 & $\mathrm{hN} 2 \mathrm{C}$ & $\begin{array}{l}\text { Navagaon: sandy clay loam, moderately erosion with } 3-5 \% \text { slope, } \\
\text { slightly gravelly }\end{array}$ & 7.8 & 1.2 \\
\hline 9 & $\mathrm{mN} 2 \mathrm{E}$ & Navagaon:, clayey, moderate erosion with $10-15 \%$ slope, narrow gullies & 46.6 & 7.0 \\
\hline 10 & $\mathrm{mN} 2 \mathrm{C}$ & Navagaon: clayey, moderate erosion with $3-5 \%$ slope, narrow gullies & 94.0 & 14.2 \\
\hline 11 & $\mathrm{~mL} 2 \mathrm{~B}$ & $\begin{array}{l}\text { Lagadwal: clayey, moderately erosion with } 1-3 \% \text { slope, moderately } \\
\text { gravelly, poorly terraced }\end{array}$ & 10.4 & 1.6 \\
\hline 12 & hL2C & $\begin{array}{l}\text { Lagadwal: sandy clay loam, moderate erosion with } 3-5 \% \text { slope, very } \\
\text { gravelly, poorly bunded and single cropped }\end{array}$ & 8.3 & 1.3 \\
\hline 13 & $\mathrm{~mL} 3 \mathrm{E}$ & $\begin{array}{l}\text { Lagadwal: clayey, severe erosion with } 10-15 \% \text { slope, very gravelly, thin } \\
\text { forest }\end{array}$ & 24.2 & 3.6 \\
\hline 14 & $\mathrm{~mL} 2 \mathrm{C}$ & $\begin{array}{l}\text { Lagadwal: clayey, moderate erosion with } 3-5 \% \text { slope, moderate gravelly, } \\
\text { double cropped }\end{array}$ & 30.4 & 4.6 \\
\hline 15 & $\mathrm{~mL} 2 \mathrm{~B}$ & $\begin{array}{l}\text { Lagadwal: clayey, moderate erosion with } 1-3 \% \text { slope, terraced and } \\
\text { double cropped }\end{array}$ & 21.0 & 3.2 \\
\hline 16 & hL2D & $\begin{array}{l}\text { Lagadwal: sandy clay loam, moderate erosion with } 5-10 \% \text { slope, } \\
\text { moderately gravelly, terraced and single cropped }\end{array}$ & 15.8 & 2.4 \\
\hline 17 & $\mathrm{mBr} 2 \mathrm{~B}$ & Brahmasila: clayey, moderate erosion with $1-3 \%$ slope, double cropped & 25.0 & 3.8 \\
\hline 18 & $\mathrm{mGa} 2 \mathrm{~B}$ & $\begin{array}{l}\text { Gaikot: clayey, moderate erosion with } 1-3 \% \text { slope, poorly bunded and } \\
\text { single cropped }\end{array}$ & 15.8 & 2.4 \\
\hline 19 & $\mathrm{mGa} 2 \mathrm{C}$ & $\begin{array}{l}\text { Gaikot: clayey, moderate erosion with 3-5\% slope, moderate gravelly, } \\
\text { poor terraced and single cropped }\end{array}$ & 24.0 & 3.6 \\
\hline 20 & mLt1B & Lagadwaltola: clayey, slightly erosion with $1-3 \%$ slope, double cropped & 18.7 & 2.8 \\
\hline 21 & $\mathrm{hLt} 2 \mathrm{~B}$ & $\begin{array}{l}\text { Lagadwaltola: sandy clay loam, moderate erosion with } 1-3 \% \text { slope, } \\
\text { double cropped }\end{array}$ & 11.9 & 1.8 \\
\hline 22 & mLth2C & $\begin{array}{l}\text { Lagadwalthana: clayey, moderate erosion with } 3-5 \% \text { slope, slightly } \\
\text { gravelly, poorly bunded land includes newly open lands occurring on } \\
\text { different slopes }\end{array}$ & 11.5 & 1.7 \\
\hline 23 & mLth2E & $\begin{array}{l}\text { Lagadwalthana: clayey, moderately erosion with } 10-15 \% \text { slope, narrow } \\
\text { gullies, poorly bunded land, slightly gravelly }\end{array}$ & 6.6 & 1.0 \\
\hline Total & & & 663.8 & 100.0 \\
\hline
\end{tabular}


Table.3 Extent and per cent of arable soil mapping unit under study

\begin{tabular}{|c|c|c|c|c|}
\hline \multirow[t]{2}{*}{ Land capability class for arable units } & \multirow{2}{*}{$\begin{array}{l}\text { Soil } \\
\text { mapping } \\
\text { unit }\end{array}$} & \multicolumn{2}{|l|}{ Area } & \multirow{2}{*}{$\begin{array}{l}\text { Suitable } \\
\text { crops }\end{array}$} \\
\hline & & ha & Per cent & \\
\hline \multirow[t]{5}{*}{$\begin{array}{l}\text { Ilet : Agriculturally versatile, but requiring a } \\
\text { higher level of inputs to achieve high } \\
\text { productivity. Slope is greater, soils more } \\
\text { variable, and the growing season is } 90 \text { to } 120 \\
\text { days under rainfed but extended to } 6 \text { to } 8 \\
\text { months if irrigation water is available. } \\
\text { Suitable for high production extensive } \\
\text { cropping with irrigation. }\end{array}$} & $\mathrm{mBh} 2 \mathrm{D}$ & 25.03 & 6.39 & $\begin{array}{l}\text { Sorghum, } \\
\text { soybean, } \\
\text { wheat } \\
\text { sunflower }\end{array}$ \\
\hline & $\mathrm{mG} 2 \mathrm{D}$ & 15.81 & 4.04 & \\
\hline & $\mathrm{mG} 2 \mathrm{C}$ & 23.95 & 6.11 & \\
\hline & iN1A & 32.68 & 8.34 & \\
\hline & Total & 97.47 & 14.67 & \\
\hline \multirow[t]{3}{*}{$\begin{array}{l}\text { IIIes :-Sound grazing and moderate cropping } \\
\text { land but limited in versatility. Growing } \\
\text { season can be limited to approximately } \\
<90 \text { days months due to dryness. With high } \\
\text { inputs, moderate to high animal production } \\
\text { may be achieved, and moderate cropping } \\
\text { yields can be achieved using high inputs and } \\
\text { minimum tillage techniques. }\end{array}$} & mL1B & 18.73 & 4.78 & $\begin{array}{l}\text { Sorghum, } \\
\text { soybean, } \\
\text { wheat }\end{array}$ \\
\hline & $\mathrm{mN} 2 \mathrm{C}$ & 112.6 & 28.75 & \\
\hline & Total & 131.33 & 19.78 & \\
\hline \multirow[t]{8}{*}{$\begin{array}{l}\text { IVst: Capable of supporting grazing under } \\
\text { moderate to low stocking rates where clearing } \\
\text { has occurred. Slopes are moderate to steep, } \\
\text { with shallow infertile soils that need care in } \\
\text { their management. Fertility levels are } \\
\text { generally low. Unsuited to cropping either } \\
\text { because of limitations due to slope, drainage, } \\
\text { lack of topsoil depth, weaker structure, low } \\
\text { water holding capacity or presence of rock. } \\
\text { High inputs may not be economic. Erosion } \\
\text { hazard is high. Forest is often the best and } \\
\text { most stable form of land use }\end{array}$} & eN2C & 78.06 & 19.93 & $\begin{array}{l}\text { Sorghum, } \\
\text { bajra }\end{array}$ \\
\hline & eN3E & 3.77 & 0.96 & \\
\hline & iN2 F & 2.96 & 0.76 & \\
\hline & iN2E & 13.94 & 3.56 & \\
\hline & $\mathrm{mL} 3 \mathrm{E}$ & 24.19 & 6.18 & \\
\hline & hL2B & 11.91 & 3.04 & \\
\hline & hB2D & 28.09 & 7.17 & \\
\hline & Total & 162.92 & 24.54 & \\
\hline
\end{tabular}


Table.4 Characteristics of soils and farm components of each category of farmers

\begin{tabular}{|c|c|c|c|c|c|}
\hline \multirow{2}{*}{$\begin{array}{l}\text { Details of } \\
\text { soils/land use }\end{array}$} & Marginal farmer(0.9ha) & Small(1ha) & Small(1ha) & Medium (3.2ha) & Medium (2.8ha) \\
\hline & Land holder $\mathbf{- 1}$ & Land holder -2 & Land holder-3 & Land holder -4 & Land holder-5 \\
\hline $\begin{array}{l}\text { Soil mapping unit/ } \\
\text { capability } \\
\text { class/soil } \\
\text { subgroups }\end{array}$ & $\begin{array}{l}\text { SMU12 -IV } \\
\text { (Typicustorthents) }\end{array}$ & $\begin{array}{l}\text { SMU18-II } \\
\text { TypicHaplusterts }\end{array}$ & $\begin{array}{l}\text { SMU-10/IV } \\
\text { TypicHaplustalfs }\end{array}$ & $\begin{array}{l}\text { SMU-18/II } \\
\text { TypicHaplusterts }\end{array}$ & $\begin{array}{l}\text { SMU-4/II } \\
\text { TypicHaplustalfs }\end{array}$ \\
\hline \multicolumn{6}{|c|}{ Participatory land use plan } \\
\hline Crop plan & $\begin{array}{l}\text { Pearl millet }+ \text { maize }+ \\
\text { soybean }\end{array}$ & Paddy + soybean & $\begin{array}{l}\text { Paddy }+ \text { soybean } \\
+ \text { maize }+ \text { pearl } \\
\text { millet } \\
\text {-onion under } \\
\text { broad bed furrow } \\
\text { system }\end{array}$ & $\begin{array}{l}\text { Paddy + soybean }+ \\
\text { maize }+ \text { pearl millet } \\
\text {-onion under broad } \\
\text { bed furrow system }\end{array}$ & $\begin{array}{l}\text { Paddy }+ \text { soybean }+ \text { maize }+ \\
\text { pearl millet } \\
\text {-onion under broad bed furrow } \\
\text { system }\end{array}$ \\
\hline Live stock & $\begin{array}{l}\text { Cow-1 + Goat }-2+ \\
\text { poultry }-10\end{array}$ & $\begin{array}{l}\text { Cow-1 + poultry - } \\
22\end{array}$ & Cow - 1 & Cow- $1+$ poultry -10 & Cow $-1+$ goat $-2+$ poultry -10 \\
\hline $\begin{array}{l}\text { Gross } \\
\text { income(Rs/ha) }\end{array}$ & $21240+60016=81256$ & $\begin{array}{l}40750+54062 \\
=94812\end{array}$ & $\begin{array}{l}30620+49848 \\
=103848\end{array}$ & $\begin{array}{l}136990+307596 \\
=444586\end{array}$ & $75300+147015=222315$ \\
\hline Benefit : cost ratio & 1.39 & 1.83 & 2.38 & 2.77 & 1.85 \\
\hline \multicolumn{6}{|l|}{ Income/day } \\
\hline crop & 16.84 & 72.63 & 45.4 & 251.16 & 88.28 \\
\hline Vegetable & & & 44.59 & 542.33 & \\
\hline Live stock & 45.11 & 29.67 & 39.31 & 54.69 & \\
\hline
\end{tabular}

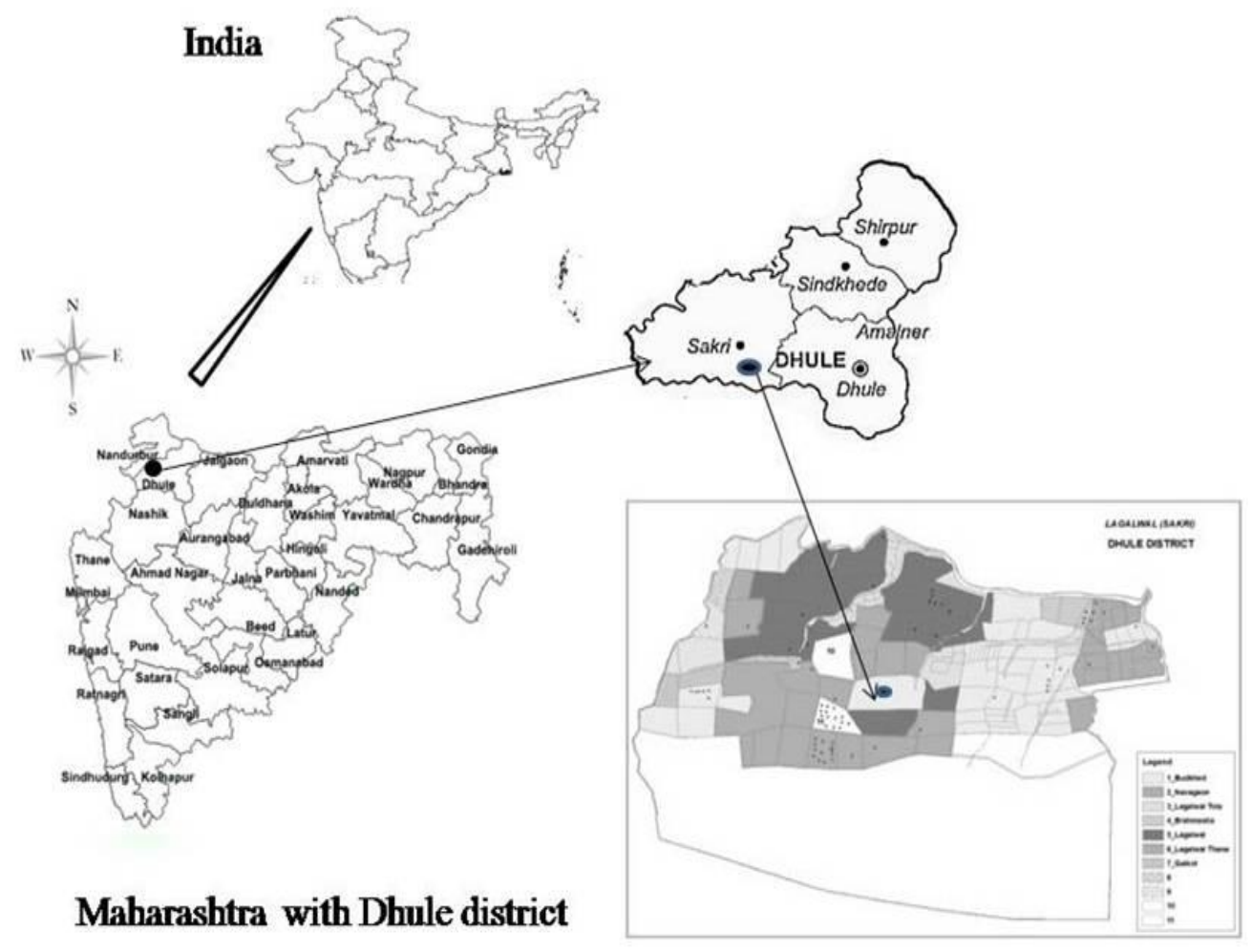

Fig.1. Location map of Lagadwal village in Maharashtra 


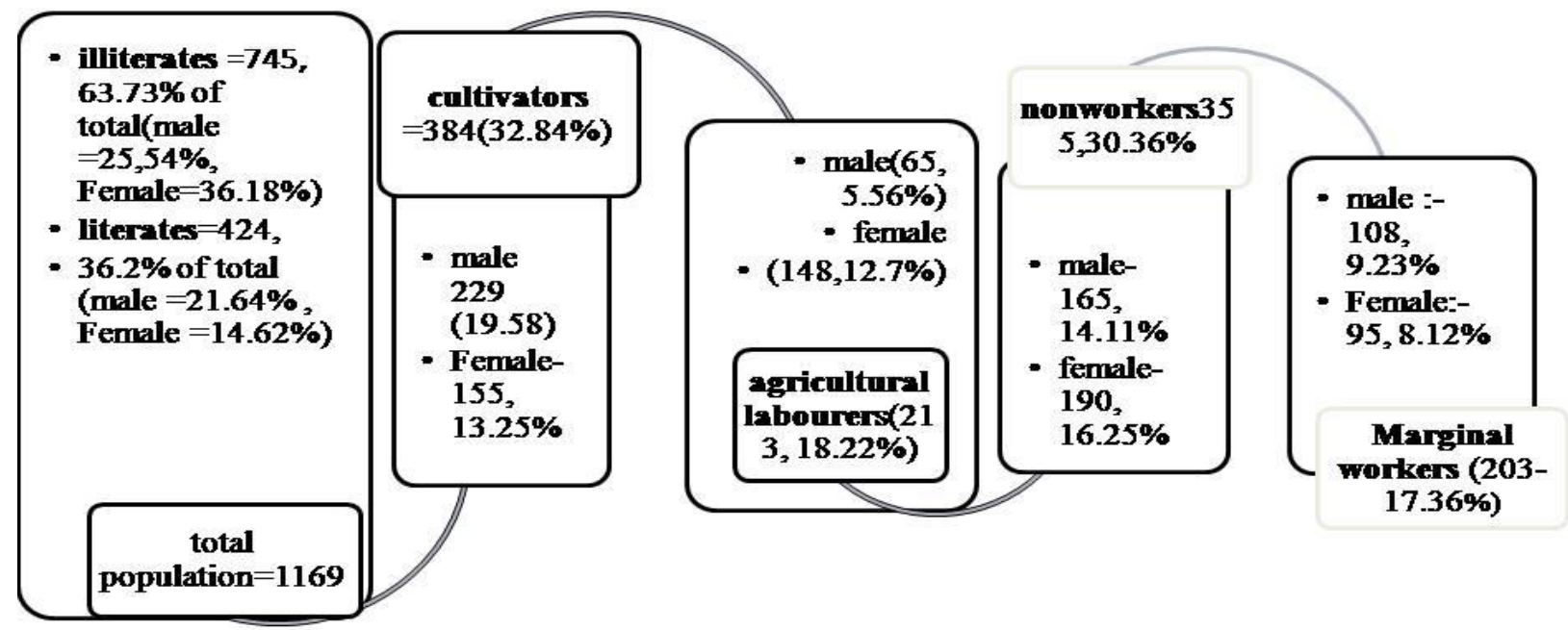

Fig.2.Demographic characteristics of Lagadwal village



Fig-3.Methodology of study 


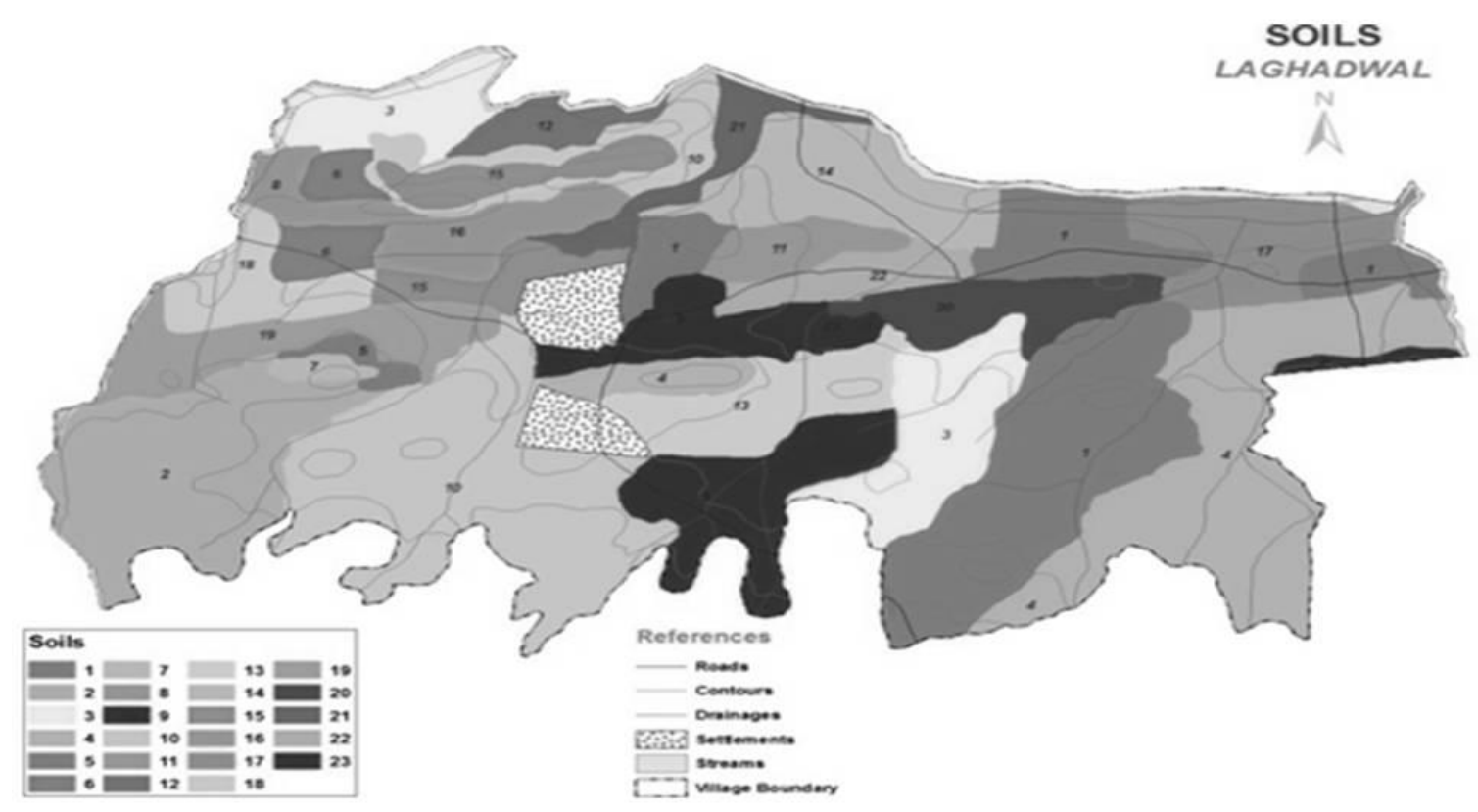

Fig-4. Soil map of Lagadwal village, Dhule district Note: soil unit numbers as shown in map is in accordance with numbers if soil units described in table 3 .

In foot slopes on low hills (3.0 per cent of total area) and gently undulating uplands on midhills (6.0 per cent of total area), Bench terraces and broad base terraces are suggested.

\section{Evaluation of participatory land-use plan}

In the present study, the crop-livestock combinations can be broadly compared in terms of how much cropping system in combination with livestock produced in different land holder in the village. This on farm trial helps to indicate what balance of crops and cropping systems might be required in the farmer's overall farming system. Turning now to an economic evaluation, the essential feature of this assessment is that crop productivity is expressed in monetary values and productivity of all systems can be easily compared in terms of a gross return. The onfarm trials with participatory land use in five selected farmers' shows perceptible changes in economic benefit under combined crop-livestock combinations (Table 4). The marginal farmer (Land holder - 1) having very shallow Typic Ustorthents with pearl millet + maize + soybean system on 0.9ha has got gross net returns of $\operatorname{Rs} 81256=00$, out of which the livestock contributes $73.8 \%$. Similarly small farmer with paddy + soybean crop plan with cow + poultry combination has earned gross income of Rs 94812=00 of which livestock contribution is 57 per cent. As the crop plan with onion under broadbed irrigation system showed an increase of increase of income to Rs 444586 (land holder 4 with 3.2ha having deep vertisols) and off Rs $222315=00$ to the land holder having Typic Haplustalfs (red soil). All five cases reported under study shows that the onion cultivation under irrigation may enhance the income along with traditional cropping system and also with livestock but under dryland 
situations, livestock almost contributes more than $70 \%$ under hot semiarid region of western Maharashtra. Similar kinds of observations were reported in forest graded area of Kandy, Sri Lanka (Ibrahim and Zemmelink, 2000). It was reported that lot of efforts have been made aiming at increasing the productivity of different components of farming system like crop, dairy, livestock, poultry, piggery, goat keeping, duckery, apiculture, sericulture, horticulture, mushroom cultivation etc. individually but lacking in their integration by following farming system approach. The integration is made in such a way that product of one component should be the input for other enterprises with high degree of complimentary effects on each other (Manjunatha et al., 2014) and from Shukla et al., (2001) in Meerut district, Uttar Pradesh. Monetary values probably offer the best solution by examining gross returns because a fixed price for any given crop / livestock can be adopted across all systems under trial and avoid confounding genuine crop-livestock aspects with locational price differences (Mahajan et al., 2015).

From the results of land resource surveys and land suitability assessments, it is deduced that lagadwal village, being a part of west Khandesh region with dry climate and narrow range of length of growing period $(<120$ days), Guhathakur and Saji, 2013 with seasonality index of 0.81 indicating rainfall regime of seasonal with prolonged drier season) supporting sorghum, bajra and soybean. The agropedological concepts were used to design economically profitable croplivestock combinations for onfarm trials with the options to increase sustainability in terms of stability and equity of crop - livestock systems. The historical productivity of crop yields are very low with the yield trends of $900 \mathrm{~kg} / \mathrm{ha}$ for bajra, $1360 \mathrm{~kg} / \mathrm{ha}$ for sorghum and $1516 \mathrm{~kg} / \mathrm{ha}$ for soybean. The critical analysis of cropping pattern and its failures as reported in the literature, the soil resource mapping using cadastral survey in basaltic terrain of Lagadwal village was absolutely necessary to generate soil-site information with in depth profile studies and their classification as seven soils series in the orders of entisols, inceptisols and vertisols according to USDA soil taxonomy (Soil Survey Staff, 2014). Twenty three phases of soil map was interpreted to delineate $58.9 \%$ arable lands, of which $24.54 \%$ of area is under capability class-IV. These land have low to moderate stock rates and good for grazing animals with shallow soils having poor fertility and subjected to severe top soil erosion hazard. During transect walks and field interviews, it was observed that farmers in the village are considered only cultivated land but not non arable lands having poor stony red soils on summits under forest cover. The tribals did not know the biophysical constraints for soybean and sunflower on shoulder slopes and summits but used moderately deep to deep black soils for sorghum in low hills. The village map was an important output at village level but would have been useless in the absence of individual detailed interviews for participatory research for shifting agricultural systems to low input under varying resource allocation (Schiere $e t$ al., 2002), rural livelihood (Cramb et al., 2004) and for bioeconomic evaluation of crop - livestock systems (Birnholz et al., 2017). The results from onfarm trials showed that the marginal farmer (< 1ha) earned Rs16.5/day from crops like soybean + maize + bajra and Rs 45 / day from livestock combination of cow (1) + goat (2) + poultry but with the inclusion of onion cultivation, the small farmer gets an additional income of Rs 45 and Rs 545 to medium farmer. To derive strong data base, the base line studies on economic evaluations and optimization of crop livestock combinations, onfarm trials testing with volunteering farmers in a traditional small 
holder sector is prerequisite in land evaluation exercises. The study concludes that intensification of crop-livestock systems is needed to increase agricultural production with efficient use of natural resources and in reducing environmental damage in tribal dominated regions.

\section{References}

AISLUS. (1970). Soil Survey Manual, IARI, New Delhi, pp. 13-61.

Bhaskar, B.P., Sarkar, D., Bobade, S.V., Gaikwad, M.S., Gaikwad, S.S., Nimkar, A.m., Anantwar, S.G., Patil, S.V. and Bhattacharyya, T.(2011). Land resource evaluation for optimal land use plans in cotton growing Yavatmal district, Maharashtra. The Ecoscan, 1:251-259.

Bhaskar, B.P., Sunil Maske, S.S. Gaikwad, A. Chaturvedi, Jagdish Prasad, S.G. Ananatwar and Singh, S.K. (2017). Soil and land resource evaluation for rural agricultural land use planning: A case study from hot semiarid ecosystem of Western India. Archives of Agronomy and Environmental Sciences, 2(3):206-218.

Brinholz, C., Bolliger, A., Tan Khanh, T., Groot, J. and Paul, B. (2017). Bioeconomic evaluation and optimization of livestock intensification in the central highlands of Vietnam. Working report of international Center for Tropical Agriculture, Nairobi, Kenya. 31p.

Chambers, R. (2003). Participation and Numbers.PLA Notes. 47: 6-12.

Cramb, R.T., Purcell, A. and Ho, T.C. (2004). Participatory assessment of rurual livelihood in the Central Highlands of Vietnam. Agricultural Systems, 81: 255-272.

Deolankar, S.B. 1980. The Deccan Basalts of Maharashtra, India - Their Potential as Aquifers. Groundwater. Lecture, Department of Geology, University of Poona, March, 434437.

Food and Agriculture Organization of the United Nations. (2007). Land evaluation Towards a revised framework. Land and Water Discussion Paper 6, Rome.

Gee, G.W., and Bauder, J.W. (1986). Particle-size analysis. p. 383-411. In A. Klute (ed.) Methods of soil analysis. Part 1. $2^{\text {nd }}$ edn. Agron. Monogr. 9. ASA and SSSA, Madison, WI.

Guhathakurta, P. and Elizabeth Saji, (2013). Detecting changes in rainfall pattern and seasonality index vis-'a-vis increasing water scarcity in Maharashtra. J. Earth Syst. Sci., 122(3): 639-649.

Ibrahim, M.N.M. and Zemmelink, G. (2000). A comparative evaluation of integrative farm models with village situation in forest garden area of Kandy, Srilanka. Asian-Aus. J. Animal Sci., 13(1):53-59.

Klingebiel, A.A. and Mongomery, P.H., (1961). Land capability classification. Agri. Handbook. 210. USDA Soil Conservation Service.

Lindsay, W.L. and Norvell, W.A. (1978). Development of a DTPA soil test for zinc, iron, manganese and copper. Soil Sci. Soc. Am. J., 42:421-428.

Mahajan, M.S., Patil, N.G., Chaturvedi, A., Bhaskar, B.P., Hajare, T.N., Deshmukh, S., Dubey, P.N. and Singh, S.K. (2015). Development of efficient farming systems through land use planning in Dhule district, Maharashtra, India. Agropedology, 25(1):110124.

Manjunatha, S.B., Shivmurthy, D., Satyareddi, S.A., Nagarajand, M.V. and Basavesha, K.N. (2014). Integrated Farming System - An Holistic Approach: A Review. Research and Reviews: Journal of Agriculture and Allied Sciences, 3(4):30-38.

Nelson, D.W. and Sommers, L.E. (1982). Total carbon, organic carbon and organic matter: In: A.L. Page, R.H. Miller and D.R. Keeney) Methods of soil analysis. Part 2 Chemical and Microbiological Properties, pp: 539-579.

Patil, H.M. and Bhaskar, V.V. (2006). Medicinal knowledge system of tribals of Nandurbar district, Maharashtra. Indian Journal of Traditional Knowledge, 5(3):327-330.

Patil, S.L. and Patil, D.A. (2007). Ethnomedicinal plants of Dhule district, Maharashtra. Natural Product Radiance.6 (2):148-151.

Santé-Riveira, I., Crecente-Maseda, R., and Miranda-Barrós, D. (2008). GIS-based planning support system for rural land-use allocation. Computers and Electronics in 
Agriculture, 63:.257-273.

Schiere, J.B., Ibrahim, M.N.M. and van Keulen, H. (2002). The role of livestock for sustainability in mixed farming: criteria and scenario studies under varying resource allocations. Agriculture, Ecosystems and Environment, 90:139-153.

Schoenneberger, PJ. Wysocki, D.A., Benham, E.C. and Soil Survey Staff. (2012). Field book for describing and sampling soils. Version-3. Natural Resources Conservation Service, National Soil Survey Center, Lincoln, NE.

Seal, A. Bera, B., Sah, K.D., Sarkar, D., Chatterjee, A.K., Bhattacharyya, P., Kim, P. and Kim, K.H. (2008). Appraisal of natural resources for data base for alternate agricultural land use at village level under saline environment: a case study from sagar islands, India. International Journal of Agricultural Research, 3:121-130

Sehgal, J.L., Saxena, R.K. and Vadivelu, S. (1987). Field Manual. Soil Resource Mapping of Different States in India. NBSS and LUP, Nagpur, pp. 73.

Sheng, T.C. (1972). A treatment oriented land capability classification for hilly land of humid tropics. In: Technical Report No. TA 3112. Food and Agriculture Organization, United Nations. Rome, Italy.

Shukla, N.D., Jagdish Prasad and Singh, S.P. (2001). Economic analysis of dairy based farming system: A case study of district Meerut.P.73. In: National Symposium on Farming System Research., UK.

Soil Survey Staff. (2014). Kellogg Soil Survey Laboratory Methods Manual. Soil Survey Investigations Report No. 42, Version 5.0. R. Burt and Soil Survey Staff (ed.). U.S. Department of Agriculture, Natural Resources Conservation Service.

Soil Survey Staff. (2014). Keys to Soil Taxonomy. Twelfth Edition, United States
Department of Agriculture. Natural Resources Conservation Service.

Srivastava, R. and Saxena, R.K. (2004). Technique of large scale mapping in basaltic terrain using satellite remote sensing data. International Journal of Remote Sensing, 25(4):679-688.

Sunitha, V., Abdullah Khan, J., Muralidhara reddy, B. and Ramakrishna reddy, M. (2011). Remote Sensing analysis of land resources for planning and development in and around Pulivendula-Sanivaripalli area, Andhra Pradesh. The Ecoscan, 5(1\&2): 27-32.

Sys, C., Van Ranst, E. and Debaveye, J. (1991). Land evaluation, Part 1: Principles in land evaluation and crop production calculations. International Training Center for Post Graduate Soil Scientists, University of Ghent, Belgium, pp. 265.

Theobald, D.M. 2005 Landscape patterns of exurban growth in the USA from 1980 to 2020. Ecol Soc 10(1):1- 32.

Velayutham, M. (2012). National Soil Information System (NASIS) and Land Resource Mapping for Perspective Land Use Planning and Pragmetic Farm Level Planning. Madras Agricultural Journal. 99(4-6):147-154.

Velayutham, M., Mandal, D.K., Mandal, C. and Sehgal, J. (1999). Agroecological Subregions of India for Development. NBSS and LUP, Publ. No. 35, 372p.

Wadodkar, M. and Ravishankar, T. (2011). Soil resource data base at village level for development al planning. Journal of the Indian Society of Remote Sensing, 31(1):43-57.

Yoganathan, G. and Meena, S. (2015). Assessment of soil physic-chemical properties, available sulphur and micronutrient status in Southern Villupuram district of Tamil Nadu using Technique. The Ecoscan, VII: 29-33.

\section{How to cite this article:}

Bhaskar, B.P., Sunil Maske, S.C. Ramesh Kumar, S. Srinivas and Rajendra Hegde. 2018. Agropedological Approach for Rural Land Use Planning - A Case Study from Lagadwal Village, Dhule District, Maharashtra, India. Int.J.Curr.Microbiol.App.Sci. 7(02): 2528-2541. doi: https://doi.org/10.20546/ijcmas.2018.702.308 